\title{
old Prussian accentuation
}

To Atie

0 . Elsewhere I have put forward my views on the origins of Baltic (Kortlandt 1973) and Slavic (Kortlandt 1974) accentuation. In these publications, which will henceforth simply be referred to by the year of publication, I have not taken into account the old Prussian material. In this paper I intend to show how the latter fits into the picture. It can be demonstrated that Old Prussian shared the common Balto-Slavic accentual innovations and that its accentual system differs from the Balto-Slavic base mainly by a single progressive accent shift, which is comparable to Dybo's law in Slavic rather than to de Saussure's law in Lithuanian. I shall confine myself to the material of the Enchiridion because this is the only source which allows definite conclusions about the Old Prussian accentual system. Moreover, I shall abstain from the use of negative evidence, that is to say, I shall not draw any conclusions from the absence of a symbol in the text. Thus, I consider the accentuation of deiws, deiwas, deiwan, deiwans unknown. For the material I refer to Trautmann 1910.

1. It is generally assumed that the macron indicates a stressed long vowel in such forms as müti, antrā, twai $\bar{a}$, turit, and the prominent part of a stressed diphthong in forms like rānkan, kaülins. In spite of Rysiewicz's objections, some of which will be discussed below, $\mathrm{I}$ adhere to this point of view. Orthographical $i j$ is equivalent to $\bar{i}$, e.g. wijrst, wirst.

Apart from the macron, the place of the stress is indicated by the presence of a double consonant, e.g. waikammans, wissamans. According to the traditional doctrine (Berneker 1896: 163, Trautmann 1910: 196f., Van Wijk 1918: 137f., Endzelin 1944: 27), a stressed short vowel is generally followed by a double consonant. This assumption does not explain the fact that double consonants are particularly frequent before stressed long vowels, cf. semme, wedde, billīt, seggĩt, skellānts, dessīmts, stallēmai, turrīlai, epwarrïsnan, enwackēmai, aupaickēmai, serrīpimai, ettrāi, tickrōmai, dellīkans, isranckĩsnan, sallübi gennāmans, tennā, tennëison. Considering that 
it is $a$ priori more probable that double consonants occur under the same conditions in word forms without a macron as they do in word forms where we can derive the place of the stress from the macron, we can formulate the following HYPOTHESIS: a double consonant indicates that the next vowel was stressed.

This hypothesis is supported by several pieces of evidence. First of all, there is a remarkable alternation between $e$ and $a$ before a double consonant in wirdemmans, waikammans and giwemmai, giwammai. The vacillation is more easily explained as the result of a pretonic neutralization than as an unmotivated alternation in the stressed syllable, ef. tennā, tannā. Secondly, it is no longer necessary to posit an ad hoc rule for the retraction of the stress in the isolated words kadden, dabber, which are clearly identical with Lithuanian kadà, dabar (cf. Trautmann 1910:101). Such a retraction could neither be phonetic (because it is not general) nor morphological (because there is no model). Thirdly, the hypothesis facilitates the derivation of Old Prussian accentuation from the Balto-Slavic base, as I shall presently demonstrate.

2. On the basis of the Slavic and East Baltic evidence I assume that the following accentual developments belong to the BaltoSlavic period (cf. 1973, section 3 and 1974, chapter 1).

(1) Loss of IE accentual mobility, except for the nominal inflexion of the consonant stems.

(2) Pedersen's law: the ictus was retracted from stressed inner syllables in mobile paradigms (Pedersen 1933: 25), e.g. Lith. dùkteri, piemeni.

(3) Barytonesis: the retraction of the ictus was analogically extended to vocalic stems in the case forms where Pedersen's law applied, e.g. Lith. ãvi, sünu, diêvq, žiẽmq. The stress was not retracted in the nom. pl. of the $o$-stems, which had a very distinct phonemic shape, ef. Lith. dievaĩ.

(4) Oxytonesis: the ictus shifted from an inner syllable to the end of the word in paradigms with end-stressed forms (Ebeling 1967: 580), e.g. Lith. sūnumì, žiemomìs.

(5) Hirt's law: the ictus was retracted if the vowel of the preceding syllable was immediately followed by a laryngeal (IllicSvityč 1963: 80f.), e.g. Lith. dúona, výras, dümai, móté, cf. Skt. dhānáh, vīráh, dhūmáh, mātâ. 
(6) Ebeling's law: the ictus was retracted from a final vowel or diphthong in disyllabic word forms unless the first syllable was closed by an obstruent, e.g. Lith. gen.sg. vilitko, dat.sg. vi lkui, gálvai, $3 \mathrm{rd}$ sg. nẽs̆a, nẽ $\check{s}$, Russ. pílo. The ictus was not retracted from closed syllables, e.g. Lith. nom. sg. galvà, gen. sg. galvõs, aviẽs, gen. pl. villũ, inst. pl. vilkaĩs, Russ. pilá from *golHváH, *golHvás, *ovéiS, *vilkó $N$, *vilkốis, *pHiláH. The laryngeals were still ordinary consonants in this period. For a discussion of this retraction I refer to section 1.4 of my study on Slavic accentuation (1974).

Now the question should be posed if Prussian shared these developments. This question is difficult to answer because traces of accentual mobility in the Enchiridion are few. Yet I think that the existing evidence confirms the above sound laws.

The mobility in spigsn $\bar{a}$, spigsnan and antra, äntran shows that Prussian shared the Balto-Slavic barytonesis as well as its prerequisite, Pedersen's law. Other pieces of evidence are mergu (with $-u$ indicating final stress), mērgan, dat. pl. mergūmans, and etwerpsnā, prakäisnan, cf. enkaitītai.

If the above hypothesis about double consonants is correct, Prussian also shared the oxytonesis, ef. wirdemmans, waikammans, wertemmai, giwassi. The combination of barytonesis and oxytonesis yielded the lateral mobility characteristic of Balto-Slavic noun inflexion.

The operation of Hirt's law in Prussian is evidenced by wijrs, nom.pl. wijrai, dat.pl. wijrimans, ef. Lith. výras, Skt. vĩráh, and by müti, Lith. móté, Skt. mātá. This law also accounts for the medial stress in mergūmans, Lith. mergóms, ef. Slovene goràm with a short $a$, and possibly for the non-final stress in billisna, powackisna, enteikūsna, cf. etwerpsnā.

The Balto-Slavic retraction which I have called Ebeling's law also reached the Prussian branch, as is clear from the mobility in laik üt, läiku. The retracted stress was generalized in the paradigm, e.g. läikumai, kirdimai, ef. kirditt. This generalization may provide an explanation for the doublet giwasi, giwassi, ef. giwit, giwu, giwammai, Russ. živu (Stang 1957: 109), živëšs'. Unfortunately, traces of accentual mobility in the noun are too scarce to offer any support for the law.

3. The Old Prussian system of accentuation is not identical to the Balto-Slavic one after the developments mentioned above. A comparison with Lithuanian shows that both languages manifest 
a progressive accent shift, but not under the same conditions. On the one hand, the stress has shifted to the desinence in semme, wedde but not in Lith. žêmé, vẽde. On the other hand, the stress has not shifted in ausins, ränkans, as opposed to Lith. ausis, rankàs. The latter examples show that de Saussure's law did not operate in Prussian, which is not surprising in view of the fact that it operated neither in Latvian (1973, section 5) nor in Slavic (Stang 1957: $15 \mathrm{ff}$.) and is fairly recent in Lithuanian. I think that the available material from the Enchiridion is satisfactorily accounted for by the following LAW: a stressed short vowel lost the ictus to the following syllable. It is possible that the law applied to stressed short vowels in open syllables only, but sufficient evidence is lacking. The law did not apply to diphthongs.

This law is reminiscent of Dybo's law for Slavic, according to which a stressed short or circumflexed vowel in a paradigm with fixed stress loses the ictus to the following syllable (Dybo 1962: 7), but it differs from the latter in two respects. First, the Prussian law applies to short vowels only. Second, it is independent of the accentual paradigm. Both laws differ from de Saussure's law in the property that the shift is independent of the intonation of the following syllable.

The form wedde could lead to the supposition that Ebeling's law did not operate in the Prussian branch. The inference is incorrect because in that case the retraction in läiku would remain unexplained. Moreover, the form semme would still require a progressive accent shift. It is simpler to assume that in wedde the ictus was first retracted in the Balto-Slavic period and then shifted to the ending after the dissolution of the linguistic unity.

The similarity between Dybo's law and the law formulated above leads to a remarkable similarity in the Slavic and Old Prussian accentuation patterns. Thus, iwai $\bar{a}$ has the same stress as Russ. tvojá, where tvoë points to final accentuation as a result of Dybo's law. The same holds true for tenna, Russ. oná, onó. The medial stress in gennāmans corresponds to Russ. žená, acc. sg. ženú, with final accentuation as a result of Dybo's law. If the above hypothesis about double consonants is correct, we have to assume fixed stress on the second syllable throughout the paradigm: gen.sg. gennas, acc.sg. gennan, nom. pl. gennai, acc. pl. gennans. This is exactly the same accentuation pattern which we find in Old Russian and in the Cakavian (Novi) dialect of Serbo-Croat (ef. Stang 1957:60). Here again the final stress in the Old Prussian forms is supported 
by the variants gannan, gannai, gannans, which point to a weak pretonic vowel. This seems by far the most straightforward explanation of the paradigm.

It is clear that the hypothesis introduced above and the law formulated in this section mutually support each other. Thus, such forms as buttan, dessimton, gallan, gemmons, gimmusin, gillin, kittan, labban, enmigguns, neggi differ from Lith. bùtas, dẽšimt, gãla, gìmęs, gimusi, gilia, kita, lãba, imiges, nègi in accordance with the law, provided that the hypothesis is correct. Notice that the hypothesis was put forward without regard to the accentual system, and that the law was formulated without reference to the hypothesis. Incidentally, the final stress in enmigguns is supported by ismige.

4. A slightly more complicated example corroborating the proposed accent shift is widdewu, dat. pl. widdewümans, where the macron points to complete correspondence with Russ. vdová, acc. sg. vdovi with final stress in accordance with Dybo's law, and Skt. vidháva. Here the double consonant offers a problem because it does not stand immediately before the stressed vowel. I think that the solution is to be found in the strongly reducing effect of the $w$ on the preceding pretonic vowel, which must have resulted in some kind of schwa. It is a rule that an occlusive preceding the pretonic vowel is doubled when the stressed vowel is preceded by intervocalic $w$, ef. reddewijdikausnan, where the long vowel marks the place of the stress, kittewidei, where the place of the stress can be derived from the form ainawidai (= ainawijdei), and pogattewinlai, which differs from Lith. pagatãvyti (Polish pogotować) as a result of the progressive accent shift. The weakness of the pretonic vowel before $w$ is reflected in the occurrence of $e$ instead of the expected $a$ in these examples, next to $a$ in kittawidin, pogattawint. The latter word is a borrowing, which suggests that the accent shift was fairly recent, cf. maddla (Polish modta), massi (Polish może), packai (Polish pokój), penningans.

Other examples of the interchange between $a$ and $e$ are found before $l, m, n$ in the first pretonic syllable, e.g. $e$ instead of $a$ in lkels $\bar{a} i$ (next to kaltzā), delliks (cf. Lith. dalykas), wesselingi (with double $s$ before the weak vowel, cf. wissawidei), wissemukin (cf. Lith. móka), wirdemmans, giwemmai, and $a$ instead of $e$ in gannan (next to gennan), waldūns (next to weldünai), cf. Trautmann 1910:100f., 105. Examples of the interchange in posttonic syllables are nom. pl. kaulei (with retraction according to Hirt's law, cf. Latvian kaũls, Greek kaulós), 
ainawijdei (next to ainawidai), and the vocatives deiwa (next to deiwe) and tāwa (next to tawe).

Apart from widdew $\bar{u}$, there are a few other cases where the macron and the double consonant do not point to the same accentuation, e.g. auppallai, pērgimmans. Though it is generally assumed that the macron in the former word is a misprint, it is equally possible that these words contained two accent frames, ef. Dutch áfvàllen. The same solution is possible for prëipirstans and buttantāws. The macron in aucktimmisk $\bar{u}$ must be a misprint, cf. deiwütisku, kanxtisku (with initial stress, as in kānxtin), labbisku (with progressive accent shift), perōnisku, seilisku (cf. nosēilis).

A final category to be discussed here are the verbs in -int, e.g. mukinna, mukinnons, mukinnimai, isrankinna, ersinnimai, ersinnati, waidinna, powaidinnei, which have final accentuation in accordance with the proposed law, cf. Lith. mokina. There are a few verbs with retracted stress in this category, e.g. dïlinai, poswäigstinai, podrüktinai, sātuinei. This type must originally have arisen as a result of Hirt's law. I think that the long vowel in the verb forms kumpinna and skijstinnons regularly marks the place of the stress, whereas the double $n$ has simply been taken from the orthography of the (very frequent) end-stressed type, cf. Lith. skaistina.

5. Since Prussian has not shared the East Baltic monophthongization (Van Wijk 1918: 65), it is reasonable to assume that it has not shared the development of metatony either (cf. 1973, sections 4-6). The only clear example of metatony in Old Prussian is the suffix -ings, which corresponds to Lith. -ingas, e.g. wertings, Lith. vertingas (cf. Bezzenberger 1907: $81 \mathrm{ff.}$., Van Wijk 1924). The falling intonation of the suffix can be explained if we start from the case where the stem preceding the suffix contained a short vowel which regularly lost the ictus to the following syllable. It is probable that the progressive accent shift, like Dybo's law, yielded a falling intonation on a newly accented long vowel or diphthong. The intonation was then generalized as a characteristic of the suffix.

If this explanation is correct, we need no longer assume a misprint in the forms podingan, pogälbenikan, of. Lith. dinga (if this form is older than diñga), pagálbininkas. The falling intonation may simply be due to the progressive accent shift. The accentuation of enwängiskan may have arisen by the analogical spread of the type, ef. Lith. véngti. No such explanation seems possible for the verbal forms pogãunai (cf. pogaūt, Lith. pagáuti) and aulāut (cf. 
aulauñsins, Lith. liáutis), though there is a type of compound verb with initial stress in Serbo-Croat (slömĩm, nàlomìm, as opposed to lòmim) and there are traces of an accentual difference between verbs with and without a prefix in Old Prussian, e.g. aupaickêmai, paikemmai.

It remains striking that all word forms with a circumflex in Old Prussian corresponding to an acute in Lithuanian are stressed on the second syllable, and that there are no forms with an acute in the former language corresponding to a circumflex in the latter. As an alternative solution, one could suggest that the intonation was neutralized in non-initial syllables.

6. Though Prussian did not share the monophthongization and the development of metatony in the East Baltic languages, it did share the shortening of long diphthongs and the rise of phonemic pitch, which may have taken place more or less independently, as in Slavic. The broken intonation which resulted from the loss of the laryngeals (1973, section 4) developed into a rising tone, as it is happening in East Latvian dialects. The other long vowels and diphthongs became falling per oppositionem. There is no trace of tonal oppositions in unstressed syllables.

Note. Old Prussian semmē and Lithuanian žẽme suggest that this word goes back to a Balto-Slavic $\bar{e}$-stem. Indeed, the final accentuation of Russ. zemljá, acc. sg. zemljú (Illič-Svityč 1963: 108) indicates that the word was still an $\bar{e}$-stem at the time when Van Wijk's law operated (cf. 1974, section 3.5). If the word had been a $j \bar{a}$-stem at that time, the stress would have been retracted as a result of Stang's law (1974, section 3.6), cf. Russ. vólja, Lith. valià. The same holds true for Russ. mežá, acc. sg. mežú, Lith. mẽde (Illič-Svityč 1963: 106).

Amsterdam

F.H.H. Kortlandt

Universiteit, Slavisch Seminarium

Spuistraat 212

\section{Glossary}

ainawidai gleich, anters ander, aucktimmiskū Obrigkeit, aulāut sterben, aupaickeèmai abdringen, aūpallai finde, äusins Ohren, billït sagen, billīsna Sprüche, buttan Haus, buttantāus Hausvater, dabber noch, deiws Gott, deiwütisku Seligkeit, dellīks Artikel, dessimton zehn, dessïmts zehnter, dillinai 
wirkt, enkaitütai angefochten, enmigguns geschlafen, enteikūsna Ordnung, enwackēmai rufen an, enwāngiskan endlich, epwarrīsnan Sieg, ersinnat erkennen, etträ $i$ antworten, etwerpsnä Vergebung, gallan Tod, gemmons geboren, gennan Weib, gillin tief, giwït leben, ismigē entschlief, isrankinna erlöst, isranckïsnan Erlösung, kadden wenn, kaltzā lauten, kānxtin Zucht, kanxtisku Zucht, kaulan Bein, kirdüt hören, kittan ander, kittawidin anders, kümpinna hindert, labs gut, labbisku Güte, laikūt leisten, maddla Bitte, massi kann, mergu Magd, mukint lehren, mūti Mutter, neggi auch nicht, nosëilis Geist, paikemmai trügen, packai Frieden, penningans Geld, përgimmans Kreaturen, perönisku gemein, podingan Gefallen, podrüktinai bestätige, pogalbenix Heiland, pogattawint bereiten, pogaūt empfangen, poswäigstinai erleuchte, powaidinnei bedeutet, powackisna Aufbietung, prakāisnan Schweiß, prēipīrstans Ringe, rānkan Hand, reddewijdikausnan falsch Zeugnis, sallübi gennāmans Ehefrauen, sātuinei sättigst, seggīt tun, seilisku Andacht, semmē Erde, serripimai erfahren, skellänts schuldig, skijstinnons gereinigt, spigsnā Bad, stallit stehen, täus Vater, tennā sie, tickrōmai gerecht, turīt haben, twais dein, waidinna zeigen, waix Knecht, waldūns Erbe, wertemmai schwören, wertīngs würdig, wesselingi fröhlich, west führen, widdewū Witwe, wijrs Mann, wirds Wort, wirst wird, wissa all, wissemukin allmächtig, wissawidei allesamt.

\section{References}

Berneker, E., 1896. Die preußische Sprache, Straßburg.

Bezzenberger, A., 1907. Studien über die Sprache des preußischen Enchiridions, Zeitschrift für vergleichende Sprachforschung 41, 65-127.

Dybo, V.A., 1962. O rekonstrukcii udarenija $\vee$ praslavjanskom glagole, Voprosy slavjanskogo jazykoznanija 6, 3-27.

Ebeling, C.L., 1967. Historical laws of Slavic accentuation, To Honor Roman Jakobson, The Hague, 577-593.

Endzelin, J., 1944. Altpreußische Grammatik, Riga.

Illič-Svity̌, V.M., 1963. Imennaja akcentuacija v baltijskom i slavjanskom, Moskva.

Kortlandt, F.H.H., 1973. On the history of Baltic accentuation, Proceedings of the First International Conference on Historical Linguistics, Edinburgh, vol. 2, 285-299.

- 1974. Slavic accentuation: A study in relative chronology, Preprint, Amsterdam.

Pedersen, H., 1933. Études lituaniennes, København.

Rysiewicz, Z., 1956. L'accontazione dell'antico prussiano, Studia jezylkoznawcze, Wrocław, 112-158 (or. in Studi baltici 7, 88-147).

Stang, C.S., 1957. Slavonic accentuation, Oslo.

Trautmann, R., 1910. Die altpreußischen Sprachdenkmäler, Göttingen.

Van Wijk, N., 1918. Altpreußische Studien, Haag.

- 1924. Ein Fall von altpreußischer Metatonie, Zeitschrift für vergleichende Sprachforschung 52, 151-152. 